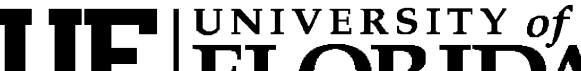 FLORIDA \\ IFAS Extension
}

ENY-853

\section{Florida's Established Arthropod Weed Biological Control Agents and Their Targets ${ }^{1}$}

\section{J. P. Cuda and J. H. Frank ${ }^{2}$}

Nonnative invasive weeds are considered to be one of the most important threats to biodiversity, second only to habitat destruction (Randall 1996, Pimm and Gilpin 1989). They interfere with crop and pasture production in agroecosystems, or alter the composition, structure and function of natural ecosystems and waterways (Pimentel et al. 2000, 2005). The losses in productivity and associated costs of controlling invasive weeds are staggering.

Pimentel et al. $(2000,2005)$ estimate the total cost of invasive weeds to the US economy is $\$ 34$ billion annually.

Compared to the rest of the continental United States, Florida is more prone to the introduction, eventual establishment, and subsequent invasion of natural communities by invasive weeds because of its unique geographic and environmental characteristics (Simberloff 1997). South Florida's extensive tropical and aquatic habitats, for example, are conducive to the establishment of nonnative terrestrial and aquatic ornamental plants. The Florida peninsula, which is bounded on three sides by water and the fourth by frost, essentially is a subtropical "island" habitat that predisposes this region to nonnative plant invasions. Florida also is dominated by novel habitats created by intense human disturbance because of its popularity as a vacation destination. During FY 05-06, the state of Florida spent a total of $\$ 31.2$ million to control aquatic and upland invasive plants on public lands (FWC 2008).

Approximately 900 out of an estimated 25,000 plant species $(\sim 4 \%)$ deliberately introduced into Florida for crop production and horticultural uses have invaded sensitive aquatic and terrestrial natural areas as well as improved pastures (Pimentel et al. 2005). One of the reasons these nonnative plants become invasive is they are introduced into an environment in which they did not evolve and therefore lack the natural enemies that limit their reproduction (Williams 1954). Biological control reunites these natural enemies (usually arthropods) with their host plants to selectively weaken and suppress the invasive weeds.

In Florida, arthropod biological control agents currently are established on seven invasive weeds: alligatorweed (Alternanthera philoxeroides (Mart.) Griseb.: Amaranthaceae), Brazilian peppertree (Schinus terebinthifolius Raddi: Anacardiaceae),

1. This document is ENY-853 (IN779), one of a series of the Entomology \& Nematology Department, Florida Cooperative Extension Service, Institute of Food and Agricultural Sciences, University of Florida. First published: September 2009. For more publications related to horticulture/agriculture, please visit the EDIS Website at http://edis.ifas.ufl.edu/.

2. J. P. Cuda, associate professor, and J. H. Frank, professor, Department of Entomology \& Nematology, University of Florida, Institute of Food and Agricultural Sciences, Gainesville, FL 32611.

The Institute of Food and Agricultural Sciences (IFAS) is an Equal Opportunity Institution authorized to provide research, educational information and other services only to individuals and institutions that function with non-discrimination with respect to race, creed, color, religion, age, disability, sex, sexual orientation, marital status, national origin, political opinions or affiliations. U.S. Department of Agriculture, Cooperative Extension Service, University of Florida, IFAS, Florida A. \& M. University Cooperative Extension Program, and Boards of County Commissioners Cooperating. Millie Ferrer-Chancy, Interim Dean 
hydrilla (Hydrilla verticillata (L. f.) Royle: Hydrocharitaceae), melaleuca (Melaleuca quinquenervia (Cav.) S.T. Blake: Myrtaceae), tropical soda apple (Solanum viarum Dunal: Solanaceae), waterhyacinth (Eichhornia crassipes (Mart.) Solms: Pontederiaceae), and waterlettuce (Pistia stratiotes L.: Araceae) (Table 1).

Various resources on Florida's weed biological control programs are available to county faculty. Extensive reviews have been published on the arthropods and biological control programs of the aforementioned invasive weeds (Buckingham 1994, Center 1994, Center et al. 2002, Van Driesche et al. 2002). Also, up-to-date information on Florida's weed biological control programs can be found on several Web sites: the aquatic weeds alligatorweed, hydrilla, waterhyacinth, waterlettuce (http://aquat1.ifas.ufl.edu/welcome. html), Brazilian peppertree (http://ipm.ifas.ufl. edu/pdf/BPmanagPlan.pdf, http://pesticide.ifas.ufl. edu/BrazilianPepper/index.shtml), melaleuca (http://tame.ifas.ufl. edu) and tropical soda apple (http://pesticide.ifas.ufl.edu/TropicalSodaApple/ index.shtml, http://ipm.ifas.ufl.edu/natural_areas/ weeds/terrestrial/TSA_Biocontrol/project.htm).

\section{References}

Buckingham, G. R. 1994. Biological control of aquatic weeds, pp. 413-480. In: D. Rosen, F. D. Bennett and J. L. Capinera (eds.). Pest management in the subtropics: biological control - a Florida perspective. Intercept, Andover, U.K.

Center, T. D. 1994. Biological control of weeds: Waterhyacinth and waterlettuce, pp. 481-521. In: D. Rosen, F. D. Bennett and J. L. Capinera (eds.). Pest management in the subtropics: biological control - a Florida perspective. Intercept, Andover, U.K.

Center, T. D., J. H. Frank and F. A. Dray, Jr. 1997a. Biological control, pp. 245-263. In: D. Simberloff, D. C. Schmitz and T. C Brown (eds.). Strangers in paradise: Impact and management of nonindigenous species in Florida. Island Press, Washington, D.C.

Center, T. D., F. A. Dray, G. Jubinsky and M. J. Godowitz. 2002. Insects and other arthropods that feed on aquatic and wetland plants. USDA, Agric. Res. Serv., Tech. Bull. 1870, Fort Lauderale, FL. 200 pp.

Cuda, J. P., R. Charudattan, M. J. Grodowitz, R. M. Newman, J. F. Shearer, M. L. Tamayo, and B. Villegas. 2007. Recent advances in biological control of submersed aquatic weeds. J. Aquat. Plant Manage. 46: 15-32.

Cuda, J. P., A. P. Ferriter, V. Manrique and J. C. Medal (eds.) 2006. Interagency Brazilian peppertree (Schinus terebinthifolius) management plan for Florida, 2nd edition: Recommendations from the Brazilian Peppertree Task Force, Florida Exotic Pest Plant Council. South Florida Water Management District, West Palm Beach, FL. http://ipm.ifas.ufl.edu/pdf/BPmanagPlan.pdf.

Frank, J. H. and E. D. McCoy. 2007. The risk of classical biological control in Florida. Biological Control 41: 151-174.

[FWC] Florida Fish and Wildlife Conservation Commission. 2008. Non-natives: Invasive plant management. http://myfwc.com/nonnatives/ InvasivePlants/index.htm (accessed 14 August 2008).

Habeck, D.H., F.D. Bennett, and J.K. Balciunas. 1994. Biological control of terrestrial and wetland weeds, pp. 523-547. In D. Rosen, F.D. Bennett, and J.L. Capinera (eds.), Pest Management in the Subtropics: Biological Control-Florida Perspective. Intercept, Andover, United Kingdom.

Julien, M. H. and M. W. Griffiths. 1998. Biological control of weeds: A world catalogue of agents and their target weeds, $4^{\text {th }}$ edition. CAB International, Wallingford.

Pimentel, D., L. Lach, R. Zuniga, and D. Morrison. 2000. Environmental and economic costs of nonindigenous species in the United States. BioScience 50: 53-65.

Pimentel, D., R. Zuniga, and D. Morrison. 2005. Update on the environmental and economic costs associated with alien-invasive species in the United States. Ecological Economics 52: 273-288. 
Pimm, S. and M. Gilpin. 1989. Theoretical issues

in conservation biology, pp. 287-305. In R.

Roughgarden, R. May, and S. Leven (eds.),

Perspectives in Ecological Theory. Princeton

University Press, Princeton, New Jersey.

Randall, J. 1996. Weed control for the preservation of biological diversity. Weed

Technology 10: 370-38.

Simberloff, D. 1997. The biology of invasions, pp. 3-18. In D. Simberloff, D.C. Schmitz, and T. C. Brown (eds.). Strangers in paradise: Impact and management of nonindigenous species in Florida. Island Press, Washington, DC.

Van Driesche, R.. S. Lyon, B. Blossey, M. Hoddle and R. Reardon (eds.). 2002. Biological Control of Invasive Plants in the Eastern United States, USDA Forest Service Publication FHTET-2002-04. USDA Forest Service, Morgantown, West Virginia, USA. pp.311-321. http://www.invasive.org/eastern/biocontrol.

Williams, J.R. 1954. The biological control of weeds. In: Report of the Sixth Commonwealth Entomological Congress, London, 7-16 July 1954.

95-98.

Table 1. Established arthropod biological control agents of invasive weeds in Florida. For higher classification and authors of scientific names of the natural enemies, see Julien and Griffiths (1998), Cuda et al. (2006, 2007), and Frank and McCoy (2007).

\begin{tabular}{|c|c|c|c|c|}
\hline Weed & Agent & Type & Origin & Date $^{1}$ \\
\hline Alligatorweed & $\begin{array}{l}\text { Agasicles hygrophila } \\
\text { Amynothrips andersoni } \\
\text { Arcola (= Vogtia) malloi }\end{array}$ & $\begin{array}{l}\text { Beetle } \\
\text { Thrips } \\
\text { Moth }\end{array}$ & $\begin{array}{l}\text { Argentina } \\
\text { Argentina } \\
\text { Argentina }\end{array}$ & $\begin{array}{l}1964 \\
1967 \\
1971 \\
\end{array}$ \\
\hline Brazilian peppertree & Megastigmus transvaalensis & Wasp & South Africa & Adventive \\
\hline Hydrilla & $\begin{array}{l}\text { Hydrellia pakistanae } \\
\text { Cricotopus lebetis }\end{array}$ & $\begin{array}{l}\text { Fly } \\
\text { Midge }\end{array}$ & $\begin{array}{l}\text { India } \\
\text { Louisiana }\end{array}$ & $\begin{array}{l}1987 \\
\text { Adventive }\end{array}$ \\
\hline Melaleuca & $\begin{array}{l}\text { Oxyops vitiosa } \\
\text { Boreioglycaspis melaleucae }\end{array}$ & $\begin{array}{l}\text { Weevil } \\
\text { Bug }\end{array}$ & $\begin{array}{l}\text { Australia } \\
\text { Australia }\end{array}$ & $\begin{array}{l}1997 \\
2002 \\
\end{array}$ \\
\hline Tropical Soda Apple & Gratiana boliviana & Beetle & South America & 2003 \\
\hline Waterhyacinth & $\begin{array}{l}\text { Neochetina bruchi } \\
\text { Neochetina eichhorniae } \\
\text { Niphograpta albiguttalis } \\
\text { Orthogalumna terebrantis }\end{array}$ & $\begin{array}{l}\text { Weevil } \\
\text { Weevil } \\
\text { Moth } \\
\text { Mite }\end{array}$ & $\begin{array}{l}\text { Argentina } \\
\text { Argentina } \\
\text { Argentina } \\
\text { North \& South America }\end{array}$ & $\begin{array}{l}1974 \\
1972 \\
1977 \\
\text { Native }\end{array}$ \\
\hline Waterlettuce & Neohydronomus affnis & Weevil & Brazil & 1987 \\
\hline
\end{tabular}

